\title{
ゴム劣化の基礎
}

\section{Basis for Degradation of Rubber}

1. は じ め に

ゴムの劣化は、ゴムがフィラーや加硫助剤等の無機物質 を含む多成分多相系であるため，非常に複雑であり，容易 に理解できるものではない，生ゴムの反応，配合剤の効 果，添加剤の効果，ゴムを製品として使用する際の環境の 影響を考慮し，総合的にゴムの劣化を理解する必要があ る。 それ故, 核磁気共鳴 (NMR) や力学物性等の緩和時 間測定および弾性率や硬度の測定等従来から行われている 分析機器を用いた測定方法では，ゴムの劣化を本質的に評 価することはできない.ゴムの劣化を種々の要素または素 反応に分割し，各要素および要素間の関係を理解すること により，正確な評価ができるようになると考えられる，本 稿では，ゴムの劣化を要素ごとに述べてから，これまでの 報告を一例として紹介する。

\section{2. 生ゴムの反応}

生ゴムは, 構成単位の構造により, 反応を分類すること ができる，さらに，使用環境に応じて反応の開始種が異な るため，生ゴムの反応を一概に述べることは難しい。ここ では，ゴムを使用する際に起こる可能性の高い反応を示す．

\section{1 自動酸化劣化}

図 1 に自動酸化劣化機構の主要な反応の一般式を示す ${ }^{1)}$. 酸化劣化は，熱，光，放射線，力学的応力などの影響によ りアルキルラジカル（R・）を生成する開始反応から始ま る。アルキルラジカルは不安定であり，十分な酸素が存在 する環境下では酸素と速やかに反応しペルオキシラジカル （ROO・）を生成する。ペルオキシラジカルは再びゴムと 反応し，それ以降は連鎖的に反応が進行する。連鎖反応 は，反応が始まると自動的に反応が継続する特徵を持つた め, このような酸化過程を自動酸化と呼ぶ. 不活性化は, ラジカル同士が結合を形成することで起こる，また，ペル オキシドの分解は，金属イオンの存在により加速される.

\footnotetext{
*東京工業高等専門学校

**長岡技術科学大学
}

\author{
山本 祥 正 ${ }^{*}$. 河 原 成 元 $^{* *}$ \\ (Received on November 21, 2017)
}

\author{
(1)開始反応 \\ $\mathrm{RH} \rightarrow \mathrm{R} \cdot+\cdot \mathrm{H}$ \\ (2)成長反応 \\ (ペルオキシドの成長)
$\mathrm{ROO} \cdot+\mathrm{RH} \rightarrow \mathrm{ROOH}+\mathrm{R}$. $\mathrm{R} \cdot+\mathrm{O}_{2} \rightarrow \mathrm{ROO} \cdot$

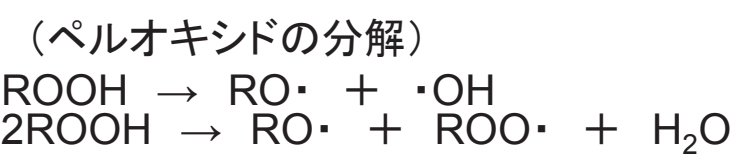

(3)停止反応

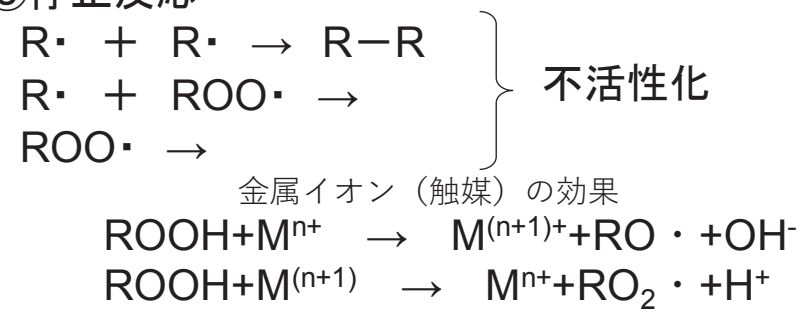

図1 ゴムの自動酸化反応

\section{2 ジェンゴム}

ジエンゴムはイソプレン単位からなるものとブタジエン 単位からなるものに大別される. イソプレン単位からなる ものは, 天然ゴムとイソプレンゴムであり, イソプレンゴ ムはZiegler系触媒を用いて重合されたcis-1,4-イソプレン 単位含有率の高いものと, Li系開始剤を用いて重合された ものに分けられる. cis-1,4-イソプレン単位は，水素引抜能 の高いラジカル種と反応してアリル位の水素が引き抜かれ 図 2 に示す 6 種のラジカルを生じる ${ }^{2)}$. これらのラジカル は酸素と反応して過酸を生じる。例えば, 眓 3 に示すよう な反応機構により反応が進行して分解が起こり, アルデヒ ドとケトンを生じる ${ }^{3-6)}$. イソプレン単位からなるジエン ゴムに光を照射したり，せん断をかけたりすると， $\beta$ 開裂 が起こり，アリルラジカルが生じる。 このアリルラジカル は, ヒドロキシラジカルと反応してアルコールを生じる ${ }^{7)}$ (図4). 
天然ゴムおよびイソプレンゴムに硫酸や塩化第二スズ, 三フッ化ホウ素, 四塩化チタン, 塩化第二鉄などのルイス 酸を作用させると図 5 に示すように環化天然ゴムが得られ る ${ }^{8-10)}$. このような環化は，アルカリ性条件下では進行 しない．環化反応によって天然ゴムおよびイソプレンゴム の比重が増加するとともに不飽和度が減少し, 硬化および 脆化する.

ブタジエン単位からなるジエンゴムは, 水素引き抜きに より生成したラジカルが優先的に再結合する。 それ故, 架 橋密度は高くなる，光を照射したり，せん断をかけたりす ると，生成したラジカルは再結合するか酸素と反応してア ルコールを生じる.

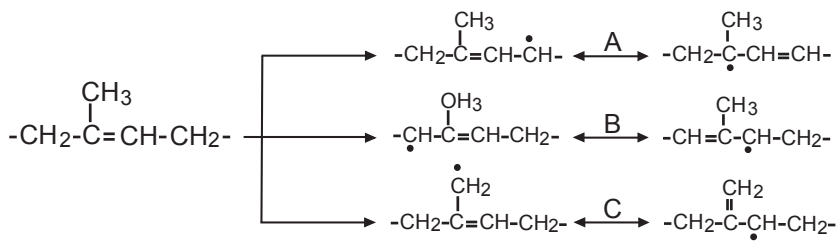
図2 cis-1,4-イソプレン単位から生じるラジカル

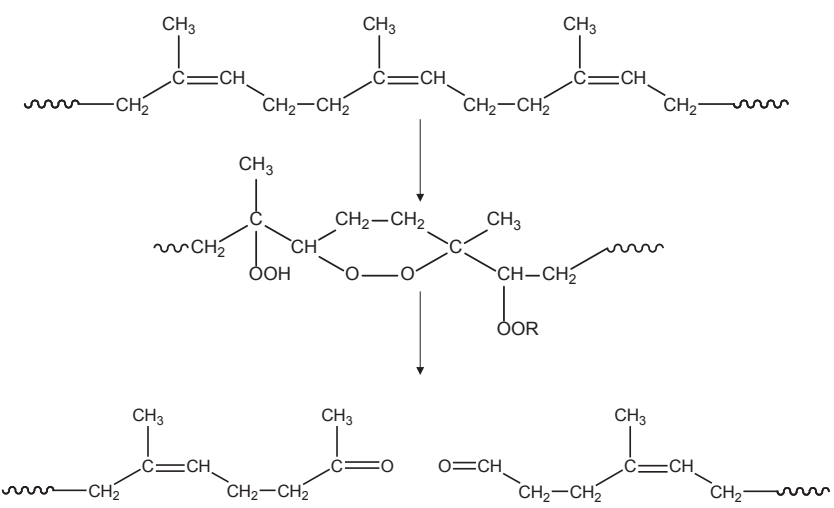

図3 天然ゴムおよびイソプレンゴムの分解<smiles>CC(=CCP)C(C)=CCCP</smiles>

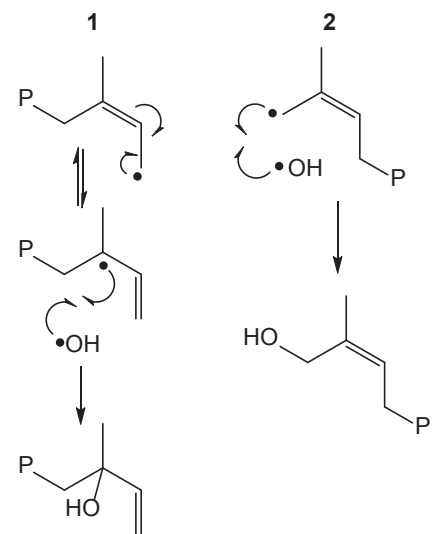<smiles>C=C(C)C(O)CPCC(C)=CC=C=C(C)C(CP)CCP</smiles>

図4光照射またはせん断により生じた天然ゴムおよびイソプレンゴ ムのラジカルの反応

\section{3 飽和炭化水素ゴム}

飽和炭化水素ゴムには, エチレンプロピレンジエンゴム $(\mathrm{EPDM})$ ，エチレンプロピレンゴム $(\mathrm{EP})$ および水素化 天然ゴムがある。水素引き抜き能の高いラジカル種が存在 するとプロピレン単位の 3 級炭素の水素が引き抜かれ，ラ

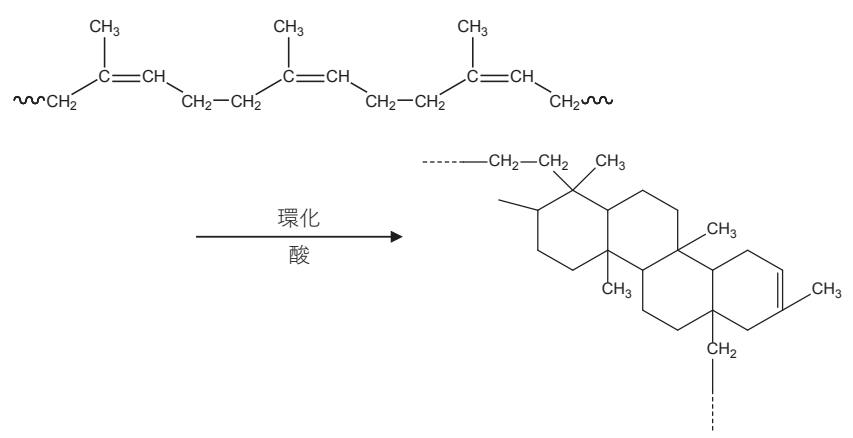

図 5 天然ゴムおよびイソプレンゴムの環化
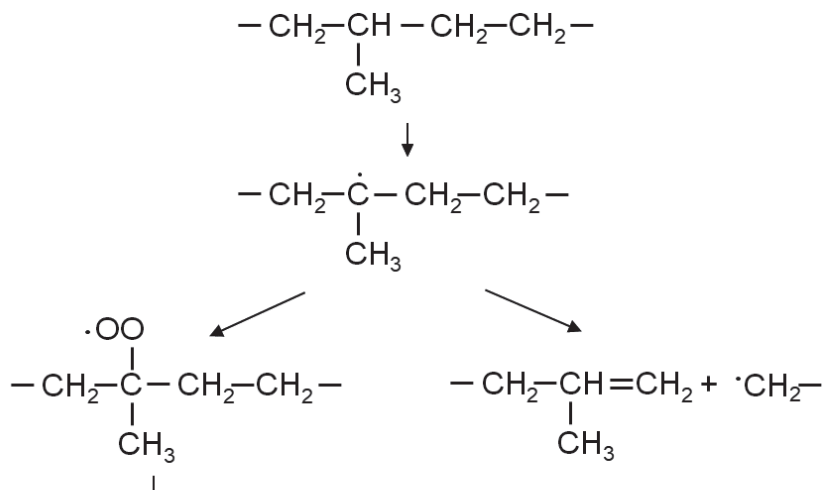<smiles>CCC[C+]C(C)=O</smiles>

図6 EPDMの分解

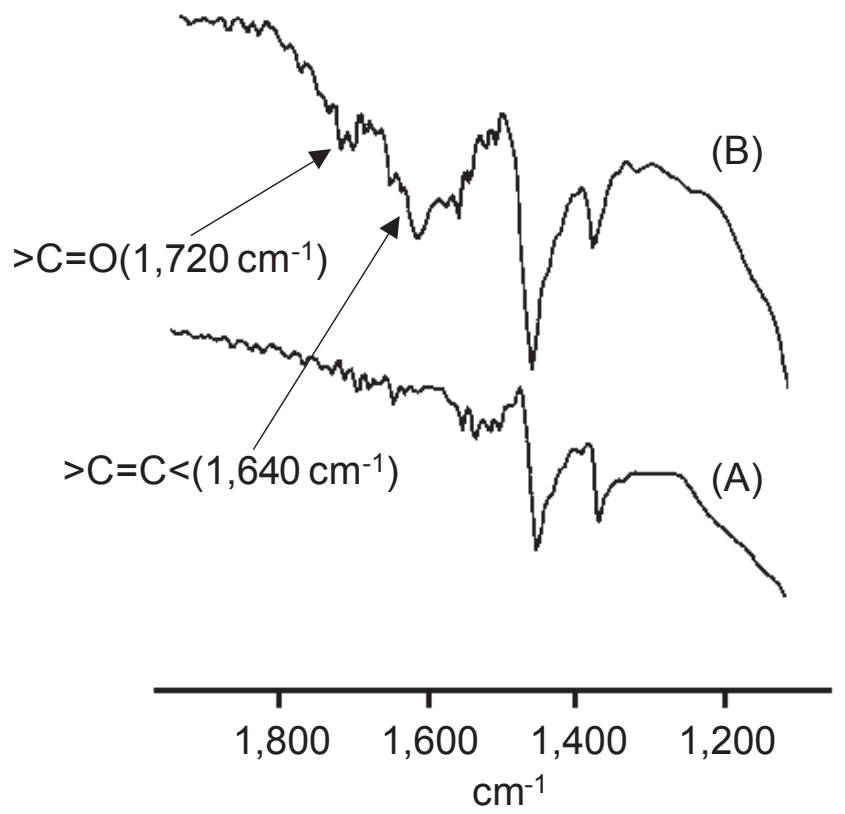

図7 未処理の EPDM（A）および劣化後の EPDM（B）のFT-IR ス ペクトル 
第 91 巻 第 3 号 $(2018)$

山本 祥 正 ·河 原 成 元

ジカルが生じ, 劣化が進行する ${ }^{11-13)}$ (図6)。また, 酸素 とラジカルが反応し，ペルオキシラジカルを経由して劣化 が進行する機構も提案されている.

図7に劣化前後のEPDMのATR-FT-IRスペクトルを示 す $^{14)}$. 未処理の EPDMのスペクトルには, $1,600 〜 1,800$ $\mathrm{cm}^{-1}$ の範囲で吸収は示されていない. しかしながら, 劣 化後の EPDM のスペクトルには, $1,640 \mathrm{~cm}^{-1}$ および 1,720 $\mathrm{cm}^{-1}$ に炭素 - 炭素二重結合およびカルボニル基に由来す る吸収が示されているＥEDMのATR-FT-IR測定より, EPDMが劣化することで炭素 - 炭素二重結合とカルボニ ル基が生じることが裏付けられている.

2.4 フッ素ゴム

フッ素ゴムは，過酷な環境であっても使用できるゴムと して知られているが，アルカリ条件下および高温条件下で 劣化することが報告されている，アルカリ条件下では，フ ッ酸が脱離し, 炭素二重結合が生成した後, $\mathrm{OH}^{-}$との反 応により分解が起こる ${ }^{15)}$ (図8). 高温条件下では, フッ素 の脱離によって生じたラジカルが連鎖的に反応する（図

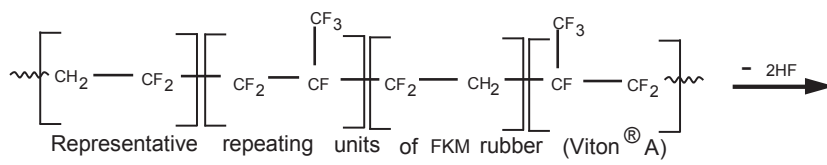
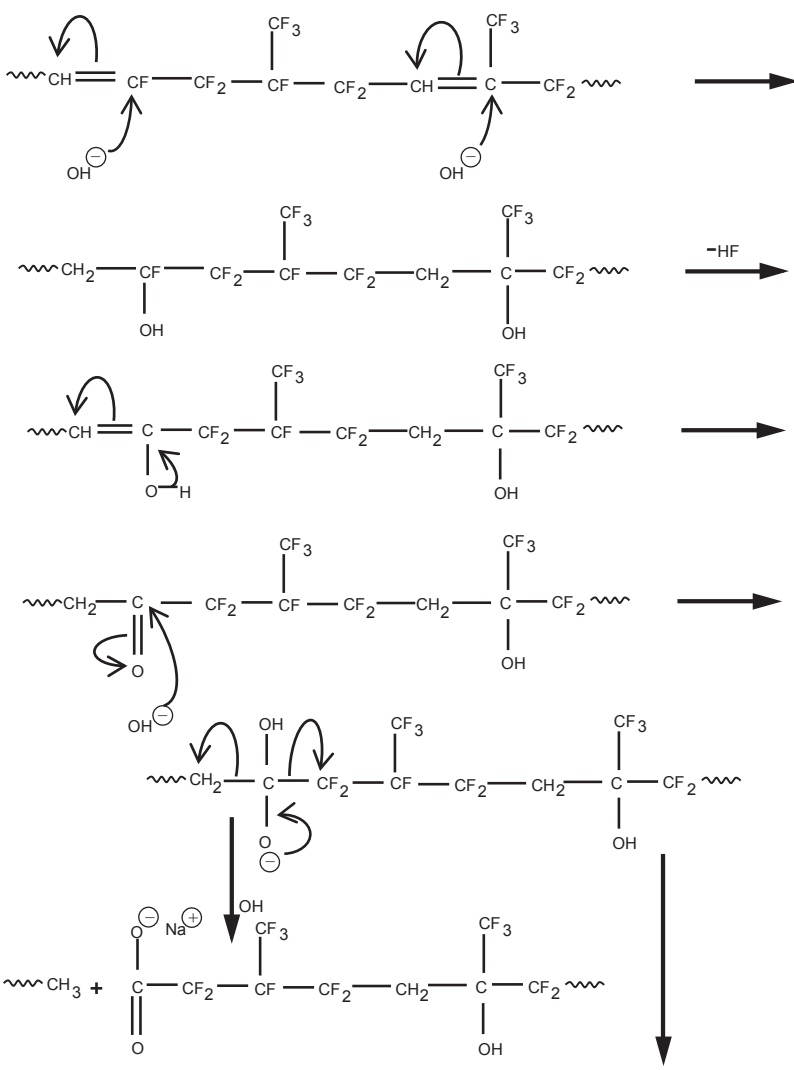<smiles></smiles>

図8 アルカリ条件下でのフッ素ゴムの分解
9). まず，フッ素ラジカルが水素を引き抜き，フッ酸が脱 離する.これにより生じた炭素ラジカルが酸素と反応して から分解が起こる ${ }^{16)}$.

2.5 シリコーンゴム

シリコーンゴムは酸性条件下およびアルカリ性条件下で 分解する ${ }^{17)}$. 酸性条件下では, シリコーンゴムが $\mathrm{H}^{+}$と反 応することにより $\mathrm{SiOH}$ および $\mathrm{Si}=\mathrm{O}$ が生じる（図 10）.

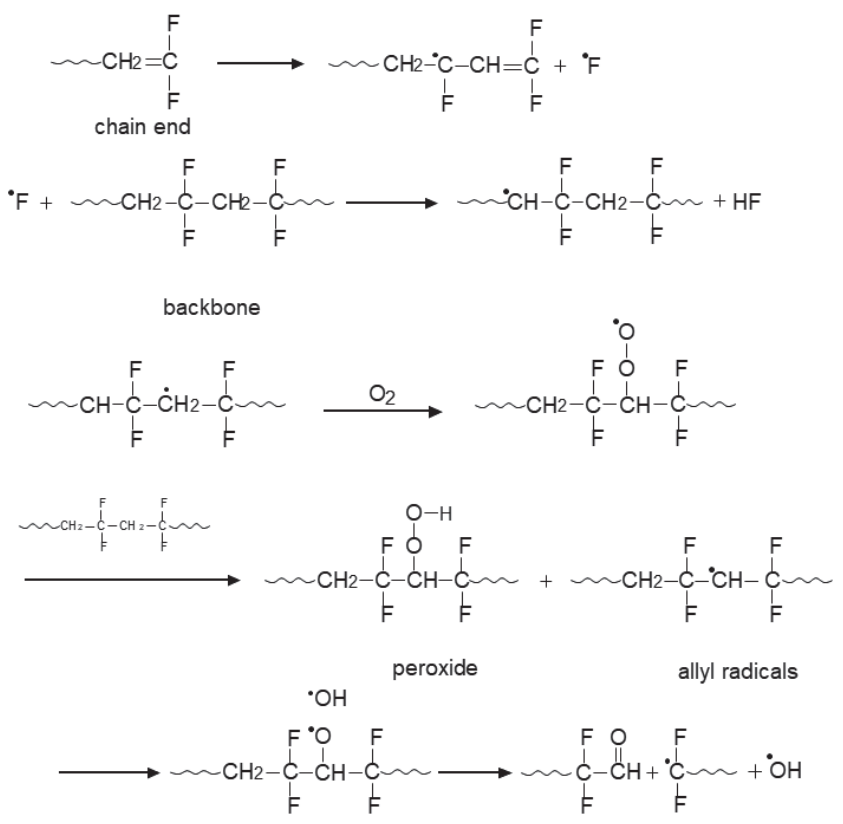

図9 高温条件下でのフッ素ゴムの分解<smiles>CO[Si](C)(C)O[Si](C)(C)C</smiles>

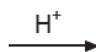<smiles>CO[Si](C)(C)[OH+][Si](C)(C)C</smiles>

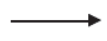<smiles>CO[Si](C)C</smiles><smiles>C[Si](C)OO[Si](C)(C)C</smiles>

図 10 酸性条件下でのシリコーンゴムの分解

Type 1

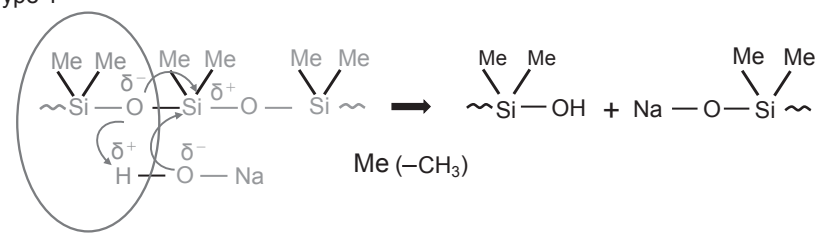

Type 2

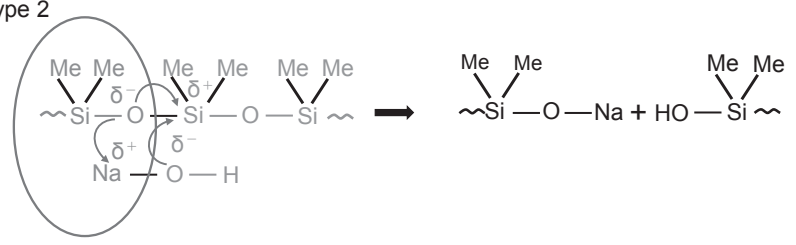

図11 アルカリ性条件下でのシリコーンゴムの分解

( 39 )

101 
一方，アルカリ性条件下では，図11に示すようにType 1 と Type 2の反応が生じる.

\section{3. 分 解後の反応}

ゴムは分解された後，種々の官能基を持つため，フィラー， 配合剂，充填郕との反応を考える必要がある。また，分解 される前には，種々の活性種を有するため，それらの反応 も考慮しなければならない。例えば，ゴムに発生したラジ カルはカーボンブラックと反応してバウンドラバーを生じ る.ゴムの物性はバウンドラバーの量に依存して変化する 18, 19)（図 12）ため，ゴムの劣化を生ゴムの反応だけで解釈 することは困難である．シリコーンゴムでは，分解後に生 じた官能基がフィラーとして充填されているシリカと反応 するため，架橋密度および硬度が高くなることが報告され

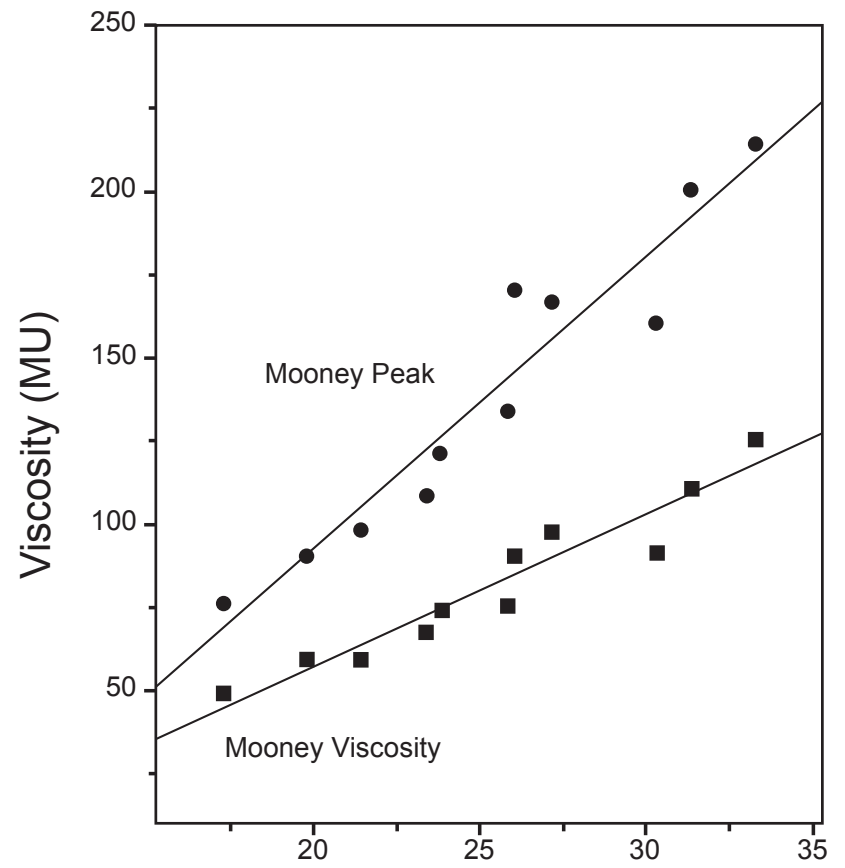

Tightly Bound Rubber Content (\%)

図 12 ムーニー粘度のバウンドラバー量依存性
$500 \mu \mathrm{m}$

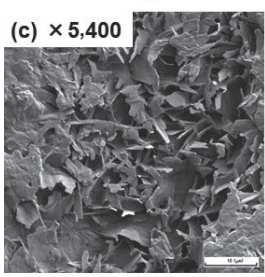

$50 \mu \mathrm{m}$

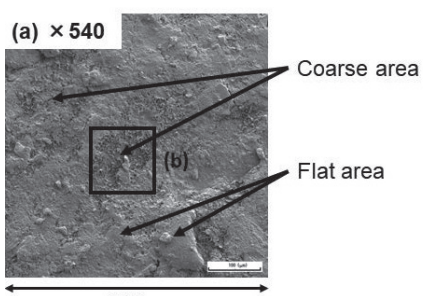

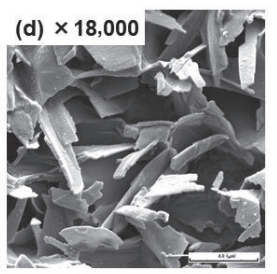

$15 \mu \mathrm{m}$

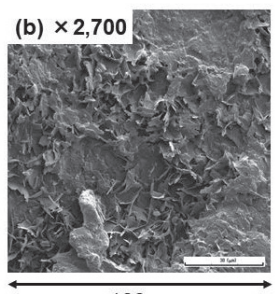

$100 \mu \mathrm{m}$

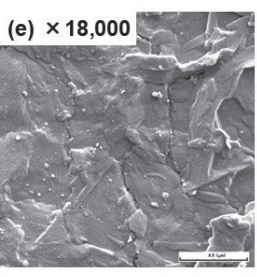

$15 \mu \mathrm{m}$
四13 未使用 EPDM パッキンのSEM像
ている ${ }^{20)}$ 。さらに, 老化防止剤, 加硫剤, 可塑剤との反応 を考慮し，ゴムの劣化を総合的に評価することが重要であ る.

\section{4. 製品として使用する際の環境の影響}

給水および給湯施設では，管接手やバルブなどの止水箇 所にEPDMがパッキンとして用いられている。図13に未 使用 EPDM パッキンのSEM像を示す ${ }^{14)}$.540倍での観察 （a）では平滑な部分と粗い部分が混在しており, 粗い部分 を2,700倍（b)，5,400倍（c）および18,000倍（d）に拡大 したSEM像に幅数 $\mu \mathrm{m}$, 厚さ $0.2 \mu \mathrm{m}$ 程度のフレーク状で あることが示されている。一方，平滑な部分を 18,000 倍 （e）に拡大したSEM像には，粗い部分で見られたフレー クが互いに重なった状態であることが示されている.

図 14 に大阪市内の給水系統において $20 \sim 45{ }^{\circ} \mathrm{C}$ で約 3 年 間使用したEPDMパッキンのSEM像を示す５40倍での 観察（a）では，異物が試料表面を覆っており，異物が存 在しない個所では表面にクラックがみられる．異物が存在 しない部分を 18,000 倍に拡大したSEM像（b）は，未使用 EPDMパッキンの平滑な部分のSEM像とほほ同じである. また, 異物部分の 2,700倍での観察（c）から, 異物のサイ ズは約 $10 〜 20 \mu \mathrm{m}$ であることがわかる。 また，クラック 部分の 5,400倍 $(\mathrm{d})$ での観察より, 幅約 $0.1 \sim 0.5 \mu \mathrm{m}$ 程度 の繊維状のものが観察され, 表面が著しく劣化しているこ とが示されている。未使用 EPDMパッキンと市場回収 $\mathrm{EPDM}$ パッキンは異なる表面形状を呈している.

図15に未使用 EPDMパッキンと市場回収 EPDMパッキ ンの表面のエネルギー分散型 X 線分光器 (EDS) による 元素分析の結果を示す。未使用 EPDMパッキンの表面の
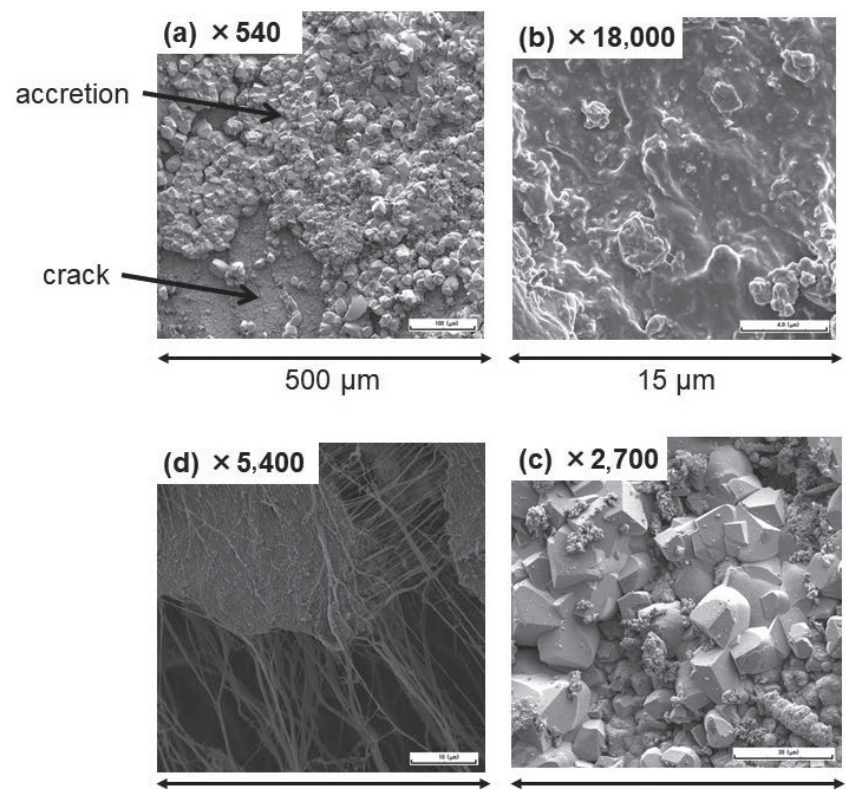

$50 \mu \mathrm{m}$

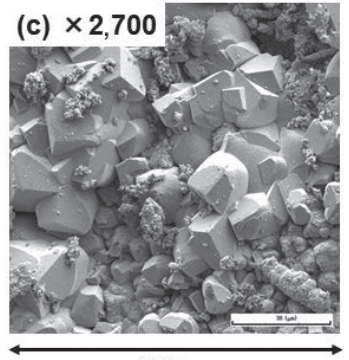

$100 \mu \mathrm{m}$

図 14 市場回収EPDM パッキンのSEM像 
EDSスペクトルには炭素と酸素のシグナルだけが示され ている. EPDMを構成している元素は炭素と水素のみで あることから, EDSに示される酸素のシグナルはパッキ ンに付着した酸素によるものと考えられる。，一方，市場回 収 $\mathrm{EPDM}$ パッキンの EDS スペクトルには，炭素と酸素と ともに鉄のシグナルが高い強度で示されている.この結果 は，図14で観察された表面の異物は鉄であることを示し ている。

収束イオンビーム (FIB) 加工は，Gaイオンビームを 試料に照射することにより数 $\mathrm{nm}$ の分解能で平滑な表面を 切り出すことができる超微細加工であり，試料内部の形態 観察に適している。図16にFIB加工により切り出した $\mathrm{EPDM}$ パッキンの断面のSEM 像を示す。未使用 EPDMパ ッキンは深さ方向に平滑な断面が観察され，マイクロメー トルオーダーでの不均一構造が存在しないことが確認でき る. 一方, 市場回収EPDMパッキンは複数の空孔が観察 される，空孔のサイズは $0.1 \mu \mathrm{m}$ から数 $\mu \mathrm{m}$ であり，複雑に 連結している。未使用 EPDMパッキンに比べて市場回収 $\mathrm{EPDM}$ パッキンは体積膨張が著しいことから，使用中に 水による膨潤と表面近傍の劣化を繰り返し，内部まで劣化

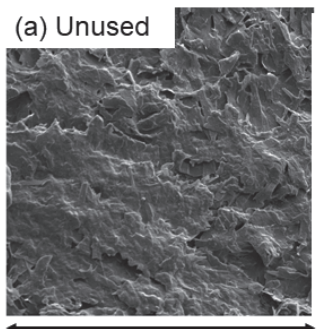

$47 \mu \mathrm{m}$

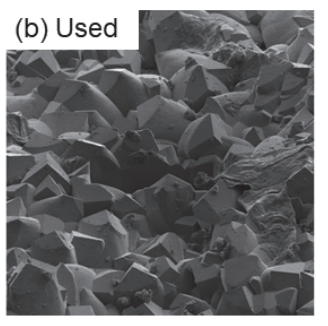

$100 \mu \mathrm{m}$
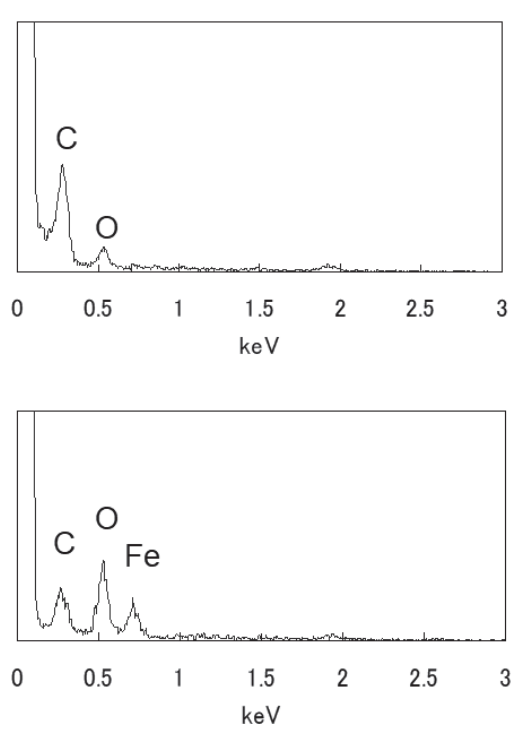

図15 未使用および市場回収EPDMパッキンの表面のEDSスペクトル
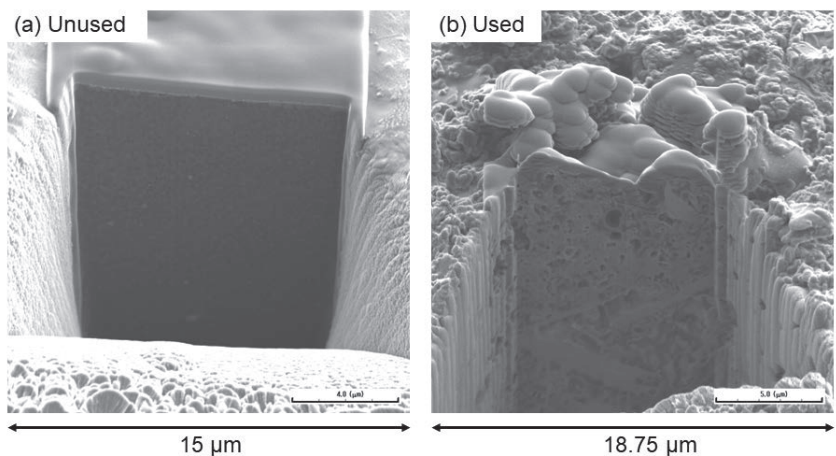

図16 未使用および市場回収 EPDMパッキンの断面のSEM像
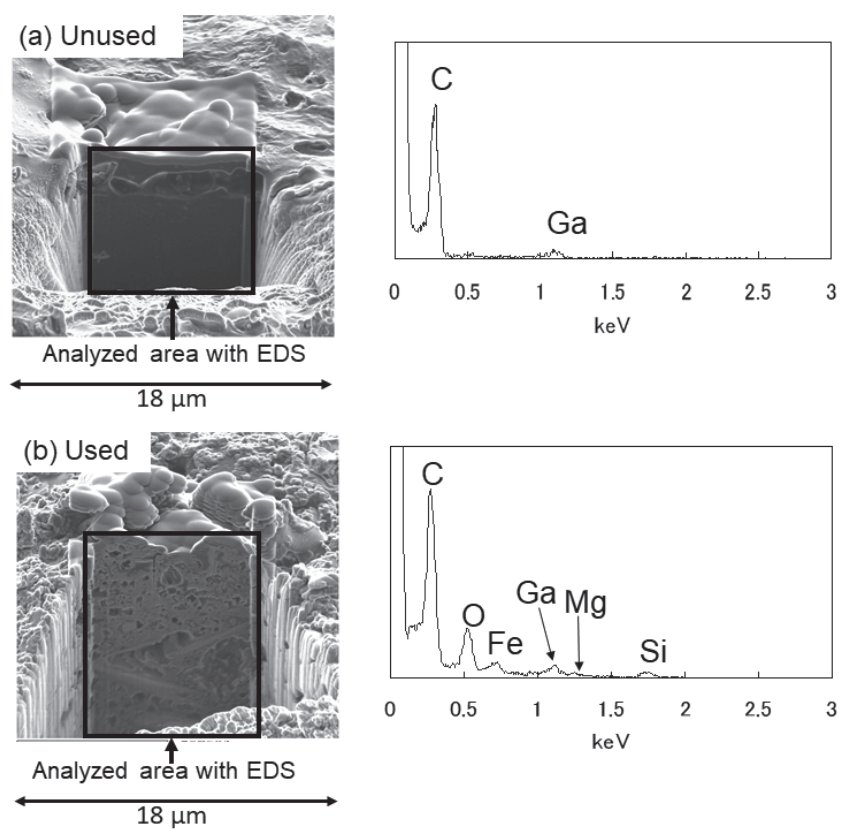

図17 未使用および市場回収EPDMパッキンの断面のEDSスペクトル

が進行したと考えられる。

未使用 $\mathrm{EPDM}$ パッキンと市場回収 EPDM パッキンの断 面の $\mathrm{EDS}$ スペクトルを図 17 に示す. 未使用 $\mathrm{EPDM}$ パッキ ンのEDSスペクトルには，炭素のシグナルのほかに小さ なガリウムのシグナルが検出されている。 これは，FIB加 工で使用するガリウム収束イオンビームが断面に付着した ため検出されたと考えられる。未使用 EPDMパッキンの EDS スペクトルには酸素や金属イオンは示されていない. 一方，市場回収EPDMパッキンのEDSスペクトルには， 炭素とガリウム以外に鉄, マグネシウム, ケイ素, 酸素の ピークが検出されている. 以上のことから, 水道水に含ま れる微量の鉄イオンやマグネシウムイオンがEPDMパッ キンの内部に浸透し，これらの金属イオンがEPDMパッ キンの劣化を促進していることが示唆される.

\section{5.お わ り に}

ゴムは, 生ゴム, 配合剤, 充填剂, 添加剤等からなる複 雑系である。それ故, ゴムの劣化は, 生ゴムの反応, 配合 剤の効果, 添加剤の効果, ゴムを製品として使用する際の 環境の影響を考慮し, 総合的に理解する必要がある.ゴム の劣化の研究には, 化学的アプローチが不可欠であり, 劣 化ゴムの構造を精緻に解析し，素反応を解明しなければな らない。また，素反応ごとに支配的な役割を果たす因子を 把握することも重要である。以上の検討により，ゴムの劣 化に関する普遍的理論が構築されることを期待する.

\section{Reference}

1 ) Osama, Z.; Narisawa, I. Ed.: "Kobunshi no Jumyoyosoku to Cyojumyoka”, NTS, Tokyo, Kisohen-1 \& Kisohen-2, Oyohen-1 (2002) 
2 ) Patterson, D. J.; Koenigh, J. L.; Shelton, J. R.: Rubber Chem. Technol., 56, 971 (1983).

3 ) Pautret, R.: Rev. Gen. Caoutch, Plast., 600, 91 (1980).

4 ) Bolland, J. L.; Hughes, H.: J. Chem. Soc., 492 (1949).

5 ) Bevilacqa, E. M.; English, E. S.; Gall, J. S.; Norling, P. M.: J. Appl. Polym. Sci., 8, 1029 (1964).

6 ) Mayo, F. R.: Ind. Eng. Chem., 52, 614 (1960).

7 ) Sakdapipanich, J.; Suksawad, P.; Insom, K.; Kawahara, S.: Rubber Chem. Technol., 78, 597 (2005).

8 ) Golub, M. A.: High Polymer, 23, 939 (1968).

9 ) Stevens, H. P.; Miller, C. J.: Rubber Chem. Technol., 12, 556 (1939).

10) Whitby, G. S.: "Synthetic Rubber", John Wiley \& Sons Inc., New York, Chapter 18 (1954).

11) Nakayama, K.; Ohtake, Y.: Nippon Gomu Kyokaishi, 83, 65 (2010).

12) Nakamura, T.; Chaikumpollert, O.; Yamamoto, Y.; Ohtake, Y.; Kawahara, S.: Polym. Degrad. Stabil., 96, 1236 (2011).

13) Ohtake, Y.; Yamamoto, Y.; Gonokami, M.; Nakamura, T.; Ishii, H.; Kawahara, S.: Polym. Degrad. Stabil., 98, 2489 (2013).
14) Gonokami, M.; Nakamura, T.; Yamamoto, Y.; Ohtake, Y.; Kawahara, S.: Seikei-Kako, 24, 335 (2012).

15) Kader, M. A.; Bhowmick, A. K.: Polym. Degrad. Stabil., 79, 283 (2003).

16) Mitra, S.; Ghanbari-Siahkali, A.; Kingshott, P.; Hvilsted, S.; Almdal, K.: J. Polym. Sci.: Part A, Polym. Chem., 42, 6216 (2004).

17) Nahar, M. S.; Zhang, J.: Am. J. Anal. Chem., 2, 363 (2011).

18) Choi, S. S.: J. Appl. Polym. Sci., 93, 1001 (2004).

19) Robertson, C. G.; Lin, C. J.; Rackaitis, M.; Roland, C. M.: Macromolecules, 41, 2727 (2008).

20) Miwa, S.; Ohtake, Y.; Kawahara, S.: Polym. Degrad. Stabil., 128, 193 (2016).

\section{日本語表記参考文献}

1 ）大澤善次郎, 成澤郁夫監修: “高分子の寿命予測と長寿命化技術”, エヌ・ティー・エス, 東京, 基礎編-1, 基礎編- 2 , 応用編 -1 (2002)

11）仲山和海，大武義人：日本ゴム協会誌，83，65（2010).

14）五野上美緒, 中村勉, 山本祥正, 大武義人, 河原成元 : 成形加 工, 24, 335 (2012). 